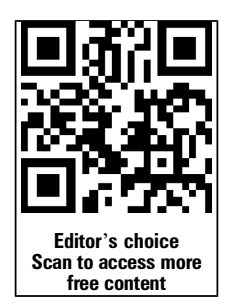

${ }^{1}$ Department of Pathology, Memorial Sloan Kettering Cancer Center, New York, New York, USA

${ }^{2}$ Marie-Josée and Henry R. Kravis Center for Molecular Oncology, Memorial Sloan Kettering Cancer Center, New York, New York, USA

\section{Correspondence to} Dr Rajmohan Murali, Department of Pathology, Memorial Sloan Kettering Cancer Center, 1275 York Avenue, New York, NY 10065, USA; MuraliR@mskcc.org

Received 10 February 2015 Accepted 11 February 2015 Published Online First 6 March 2015
CrossMark

To cite: Conlon $\mathrm{N}$, Soslow RA, Murali R. J Clin Pathol 2015;68:418-426.

\title{
Perivascular epithelioid tumours (PEComas) of the gynaecological tract
}

\author{
Niamh Conlon, ${ }^{1}$ Robert A Soslow, ${ }^{1}$ Rajmohan Murali ${ }^{1,2}$
}

\begin{abstract}
Perivascular epithelioid tumours (PEComas) of the gynaecological tract are rare tumours which were first recognised and diagnosed within the last 20 years. They represent a unique diagnostic challenge with regard to their accurate and reproducible distinction from more common entities such as smooth muscle tumours of the uterine corpus. In this review article, we trace the development of the concept of the PEComa tumour family, highlight what is known about extragynaecological tract PEComa at an immunohistochemical, molecular and therapeutic level and then present a summary of all reported cases of gynaecological tract PEComa to date. In the summary, we highlight rare subtypes of gynaecological tract PEComa and compare the performances of extant prognostic classification systems for malignancy in these tumours.
\end{abstract}

\section{INTRODUCTION: PECOMA}

Demonstration of the expression of the melanocytic marker HMB-45 in angiomyolipoma (AML) ${ }^{12}$ and clear cell 'sugar' tumours (CCSTs) of lung ${ }^{3}$ led to the concept of PEComa as a family of tumours occurring at many sites and characterised by the presence of an epithelioid cell of mixed myomelanocytic immunophenotype. This family included previously recognised entities such as AML, CCST, lymphangioleiomyomatosis (LAM) and clear cell myomelanocytic tumour of the falciform ligament/ ligamentum teres. Subsequently, sporadic HMB-45positive clear cell tumours of other sites such as pancreas ${ }^{4}$ and uterus ${ }^{5}$ were described.

The cell of origin of PEComas has not been unequivocally established. Early reports speculated tumour origin from vessel walls ${ }^{6}$ or from a 'peculiar muscle cell' based on morphology and expression of myomelanocytic markers. ${ }^{3}$ Embryological and in vitro studies have provided evidence for origin from a neural-crest stem cell that is capable of myoid and melanocytic differentiation during embryological development and has also been demonstrated in the context of tissue repair. ${ }^{7-11}$

Tuberous sclerosis complex (TSC) is characterised by the development of tumours at various sites, including brain, heart and kidney. Genetically, TSC is associated with mutations in TSC1 or TSC2 (located on 9q 34 and 16p13 respectively), leading to impaired production of the proteins hamartin and tuberin, respectively. TSC1 and TSC2 interact as heterodimers that inhibit the mechanistic target of rapmycin (mTOR) pathway; their inactivation leads to increased cell growth and proliferation. ${ }^{12}$ The prototypical PEComa associated with TSC is renal AML. While $\sim 80 \%$ of patients with TSC have AML, $<50 \%$ of all renal AMLs and $<10 \%$ of extrarenal AML occur in patients with TSC. ${ }^{13}$ The majority of reported cases of PEComatosis (widespread multifocal macroscopic and microscopic nodules of PEComa cells involving multiple sites in the gynaecological tract and pelvis) have occurred in TSC patients, ${ }^{14-18}$ while the uterus of a single TSC patient harboured a subserosal AML, a sclerosing PEComa of lower uterine segment and diffuse LAM of the uterine corpus. ${ }^{19}$ Thus, TSC-associated loss of function of TSC1/TSC2 can lead to a phenotypic spectrum (classical AML-like, classical PEComa, sclerosing PEComa, LAM) that is also recognised in sporadic PEComas.

Histologically, PEComa is characterised by the presence of predominantly epithelioid cells with clear, granular or eosinophilic cytoplasm, arranged in nests or sheets, with little intervening stroma (figure 1A-D). Many PEComas have a low mitotic rate of $0-1$ per 50 high power fields (HPFs). Areas of necrosis may be seen (figure 2A). PEComas demonstrate varying levels of nuclear pleomorphism, including multinucleate giant cells (figure 2B) and 'spider cells', analogous to those seen in cardiac rhabdomyoma. ${ }^{20}$ Other features include macronucleoli (figures $1 \mathrm{C}$ and $2 \mathrm{~B}$ ) and intranuclear pseudoinclusions (figure 1C). ${ }^{20}$ While most reported PEComas have been epithelioid, they show a cytological spectrum from purely spindled to purely epithelioid (and combinations of the two). Rare features include sex-cord-like features ${ }^{21}$ and prolactin secretion. 2223

Sclerosing PEComa occurs predominantly in the retroperitoneum of women and rarely in the uterus and pelvis. They show cords of epithelioid cells within densely sclerotic stroma. Areas of intimate association between tumour cells and blood vessels are often identified. ${ }^{24}$

PEComas are defined by the immunohistochemical (IHC) coexpression of myoid markers (smooth muscle actin (SMA), desmin, caldesmon) and melanocytic markers (HMB-45, Melan-A, microphthalmia-associated transcription factor (MiTF)). Expression varies with morphology: tumours with predominant spindle cell morphology show strong expression of muscle markers and limited expression of melanocytic markers; predominantly epithelioid tumours may strongly express melanocytic markers with limited muscle marker expression. Recently, cathepsin $\mathrm{K}$, a transcriptional target of the MiTF family, emerged as a sensitive marker for PEComa. ${ }^{25-27}$ However, cathepsin $\mathrm{K}$ is not specific for PEComa and is commonly positive in melanoma, alveolar soft part sarcoma and mesenchymal tumours, including leiomyosarcoma (LMS). ${ }^{28}$

Renal and extrarenal AMLs/PEComas exhibit true melanocytic differentiation in the form of 

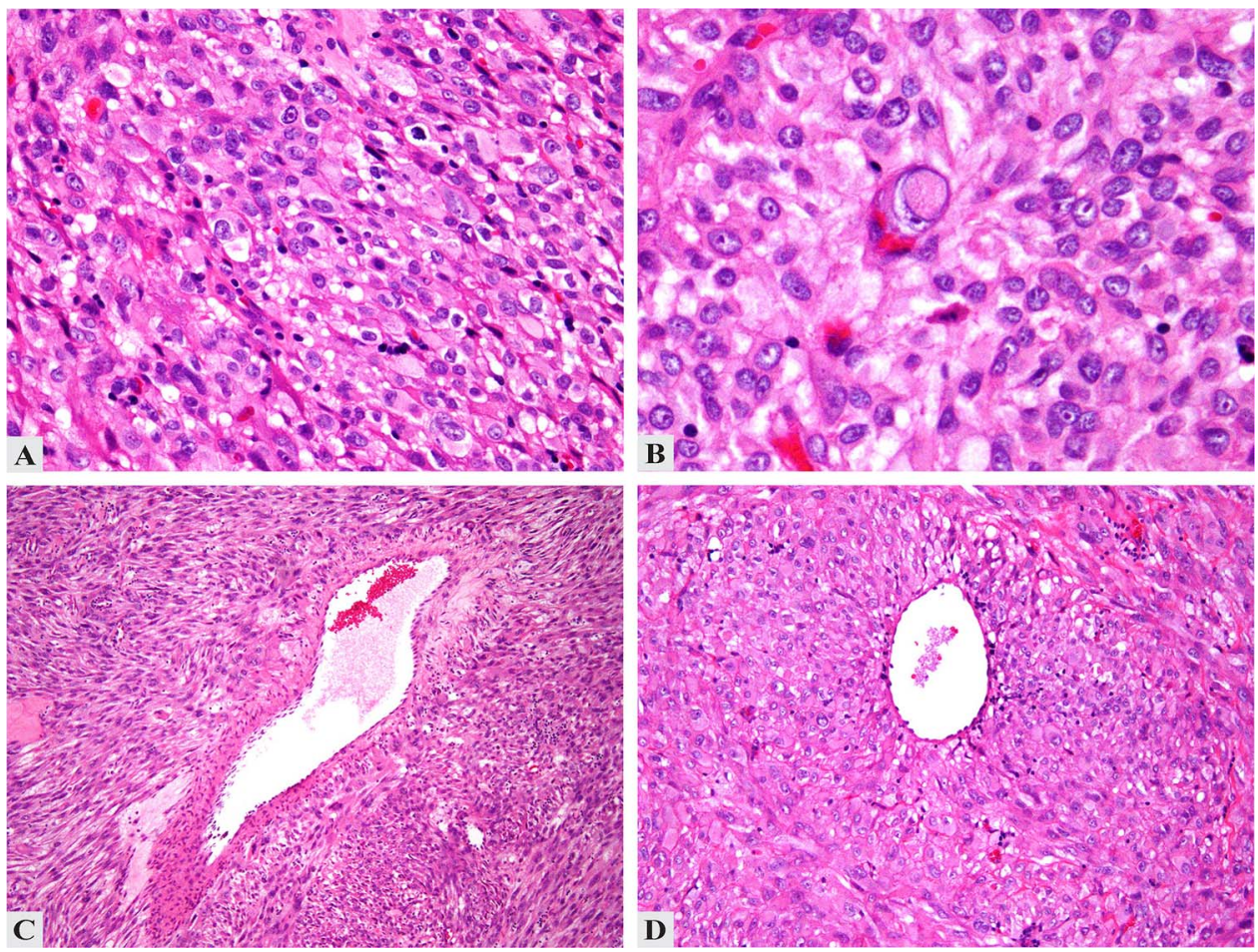

Figure 1 Histopathological features of uterine perivascular epithelioid tumour. (A) Sheets of epithelioid cells without intervening stroma. (B) Cells with abundant eosinophilic, fibrillary cytoplasm, prominent nucleoli and occasional nuclear pseudoinclusions. (C and D) Perivascular cuffing by tumour cells.

melanosomes at various stages of development on electron microscopy 2930 and positive Masson-Fontana staining. Grossly and microscopically pigmented examples of PEComa have been reported. ${ }^{31-34}$

Limited genomic studies have suggested that loss of heterozygosity (LOH) at the TSC2 locus may play an important role in sporadic PEComa tumourigenesis, similar to its role in TSC-related and sporadic renal AML ${ }^{35-37}$ and sporadic pulmonary LAM. ${ }^{38}$ Comparative genomic hybridisation on nine PEComas (including one uterine case) showed multiple chromosomal imbalances, with $16 \mathrm{p}$ loss in six cases and $\mathrm{X}$-chromosomal gains in six cases. ${ }^{39}$ Malinowska et $a l^{40}$ demonstrated loss of IHC expression of tuberin in four PEComas and LOH or allelic loss of at least one TSC2 microsatellite marker in two of those four cases. Kenerson et $\mathrm{al}^{41}$ reported IHC evidence of mTOR pathway activation (increased levels of phosphop70S6K, reduced levels of phospho-AKT and loss of tuberin expression) in sporadic AMLs and extrarenal PEComas. Based on these limited studies, several clinical trials of mTOR pathway inhibitors in malignant PEComa have been initiated.

\section{PECOMA OF THE GYNAECOLOGICAL TRACT Uterine corpus}

To date, 78 cases of uterine corpus PEComas have been reported in the English-language literature (table 1). $.^{5} \quad 16-20 \quad 24 \quad 39 \quad 42-72$ Tumour morphology was described in 74 cases (table 1). A summary of the reported IHC findings is presented in table 2 . A mixed myomelanocytic phenotype, with positivity for at least one melanocytic and one muscle marker, was confirmed in 66 of $73(90 \%)$ cases. The remaining tumours 444548 (including three transcription factor E3 (TFE3)-translocation-associated PEComas ${ }^{71}$ ) were HMB-45-positive but negative for multiple muscle markers. ${ }^{71}$ On ultrastructural examination, seven of
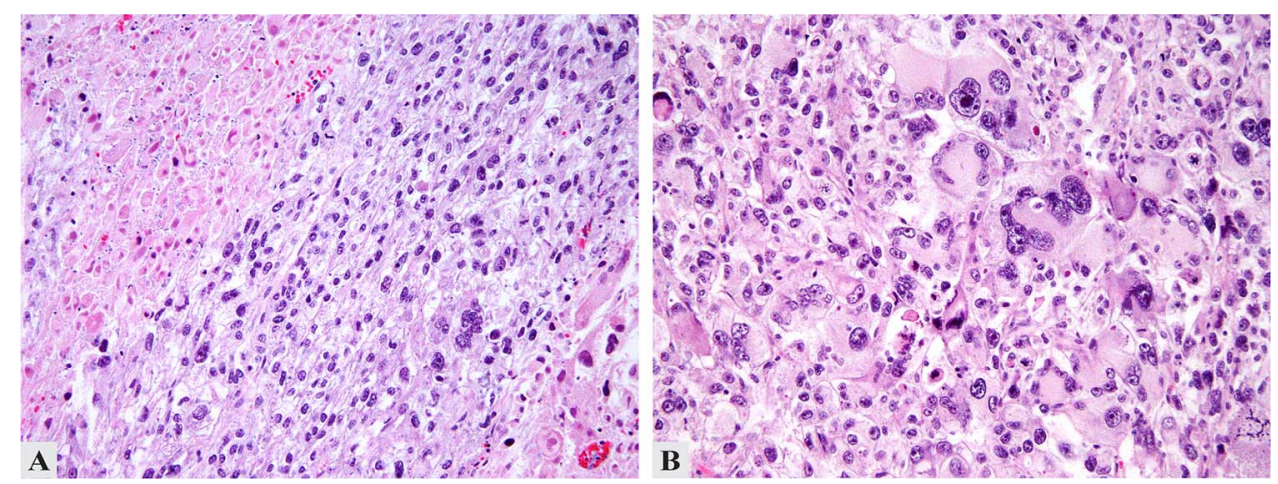

Figure 2 Malignant perivascular epithelioid tumour of uterus. (A) Pleomorphic tumour with necrosis (upper left). (B) Multinucleate tumour cells with macronucleoli. 
Table 1 Summary of clinicopathological features of PEComas of the gynaecological tract

\begin{tabular}{|c|c|c|c|c|c|c|}
\hline & Uterine corpus & Cervix & Vagina & Adnexa & Broad ligament & Vulva \\
\hline $\mathrm{N}$ & 78 & 11 & 7 & 6 & 5 & 1 \\
\hline Age at diagnosis, median (range), years & $47.5(9-79)$ & $46(25-61)$ & $28(6-57)$ & $49(33-63)$ & $25(24-57)$ & 20 \\
\hline \multicolumn{7}{|l|}{ Associations } \\
\hline TSC & $5(6 \%)$ & $1(9 \%)$ & - & $2(33 \%)$ & - & \\
\hline Other PEComa family tumours & $\operatorname{LAM}(n=3)$ & - & - & - & - & \\
\hline PEComatosis & $4(5 \%)$ & $1(9 \%)$ & - & - & - & \\
\hline Tumour size, median (range), cm & $\begin{array}{l}5(0.2-30) \\
(n=67)\end{array}$ & $\begin{array}{l}3.9(1-12) \\
(n=9)\end{array}$ & $\begin{array}{l}3(1.5-9) \\
(n=5)\end{array}$ & $\begin{array}{l}4.2(2.5-15) \\
(n=6)\end{array}$ & $\begin{array}{l}11.5(4-17) \\
(n=5)\end{array}$ & 2 \\
\hline \multicolumn{7}{|l|}{ Morphology } \\
\hline Sclerosing PEComa & $9(12 \%)$ & 0 & 0 & $2(33 \%)$ & $1(20 \%)$ & \\
\hline Cell shape & & - & & & & \\
\hline Epithelioid & $43 / 74(58 \%)$ & & $6 / 7(86 \%)$ & & $2 / 4(50 \%)$ & \\
\hline Spindle & $1 / 74(1 \%)$ & $6 / 10(60 \%)$ & - & $3 / 6(50 \%)$ & $1 / 4(25 \%)$ & \\
\hline Epithelioid+spindle & $30 / 74(41 \%)$ & $4 / 10(40 \%)$ & $1 / 7(14 \%)$ & $3 / 6(50 \%)$ & $1 / 4(25 \%)$ & \\
\hline Necrosis & $31 / 74(42 \%)$ & $4 / 10(40 \%)$ & $1 / 5(20 \%)$ & $2 / 6(33 \%)$ & $3 / 4(75 \%)$ & - \\
\hline Nuclear atypia & $\begin{array}{l}\text { Significant, severe or } \\
\text { extensive in } 25 / 62(40 \%)\end{array}$ & $\begin{array}{l}\text { Moderate to } \\
\text { severe in } 7 / 10(70 \%)\end{array}$ & $\begin{array}{l}\text { Severe atypia } \\
\text { not seen }(5 / 5,0 \%)\end{array}$ & $\begin{array}{l}\text { 'Severe'/'significant' } \\
\text { atypia in } 4 / 6(67 \%)\end{array}$ & $\begin{array}{l}\text { Varying from } \\
\text { none to severe }\end{array}$ & None \\
\hline Mitotic activity & $\begin{array}{l}\leq 1(38,52 \%) \\
\text { Rare }(7,10 \%) \\
2-222 \text { per } 50 \text { HPF }(28,38 \%) \\
(n=73)\end{array}$ & 'Zero', 'rare' or $\leq 1 / 50$ HPF $(8 / 9,89 \%)$ & Absent or 'rare' $4 / 5(80 \%)^{*}$ & Variable: $\leq 1(3 / 6)$ to $97 / 50 \mathrm{HPF}$ & & Rare \\
\hline $\mathrm{IHC}$ & (see also table 2) & & & & & \\
\hline HMB-45 & $71 / 72(99 \%)$ & $8 / 8(100 \%) \dagger$ & $6 / 6(100 \%) \ddagger$ & $6 / 6(100 \%)$ & $4 / 4(100 \%)$ & $1 / 1(100 \%)$ \\
\hline Melan-A & $21 / 46(46 \%)$ & $4 / 5(80 \%)$ & $1 / 4(25 \%)$ & $3 / 3(100 \%) \S$ & $1 / 3(33 \%)$ & \\
\hline MiTF & $14 / 21(67 \%)$ & & 0/1 (0\%) & $1 / 1(100 \%) \uparrow$ & & \\
\hline SMA & $53 / 68(80 \%)$ & $5 / 8(63 \%)$ & $2 / 4(50 \%)$ & $4 / 5(80 \%)$ & $4 / 4(100 \%)^{* *}$ & \\
\hline Desmin & $39 / 62(63 \%)$ & $3 / 5(60 \%)$ & $0 / 2(0 \%)$ & $4 / 6(67 \%)$ & $1 / 2(50 \%)+\dagger$ & $0 / 1(0 \%)$ \\
\hline Caldesmon & $17 / 22(77 \%)$ & & & $2 / 2(100 \%)$ & & \\
\hline Cytokeratin & $2 / 43(5 \%)$ & & & & & \\
\hline Oestrogen receptor (ER) & $10 / 19(53 \%)$ & & & & & \\
\hline Progesterone receptor (PR) & $11 / 13(85 \%)$ & & & & & \\
\hline PAX8 & 0 & & & & & \\
\hline CD10 & $4 / 28(14 \%)$ & & & & & \\
\hline CD34 & 0 & & & & & \\
\hline Vimentin & $11 / 18(61 \%)$ & & & & & \\
\hline Inhibin & $1 / 20(5 \%)$ & & & & & \\
\hline \multicolumn{7}{|l|}{ Follow-up } \\
\hline Duration, median (range), months & $20(1.5-168)$ & $28(9-42)$ & $14.5(3-54)$ & $9(4-72)$ & $13.5(11-18)$ & 48 \\
\hline Died of disease & $10 / 63(16 \%)$ & $1 / 9(11 \%)^{78}$ & - & $1 / 4(25 \%)$ & - & - \\
\hline No evidence of disease & $44 / 63(70 \%)$ & $8 / 9(89 \%)$ & $6 / 7(86 \%)$ & $3 / 4(75 \%)$ & $2 / 4(50 \%)$ & $1 / 1(100 \%)$ \\
\hline Alive with disease & 9/63 (14\%) & - & $1 / 7(14 \%)$ & & $2 / 4(50 \%)$ & - \\
\hline
\end{tabular}

${ }^{*}$ A single transcription factor E3 translocation-associated case had a mitotic count of five per 50 HPF.

tStrong or diffuse in six of six cases.

\#Strong or diffuse in three of three cases.

\$Focally weakly positive in two of three cases and was strongly positive in one of three cases.

IWeakly positive in less than half of tumour cells.

** Focally positive in two tumours.

HPF, high power field; IHC, immunohistochemical; LAM, lymphangioleiomyomatosis; MiTF, microphthalmia-associated transcription factor; PEComas, perivascular epithelioid tumours; TSC, tuberous sclerosis complex.

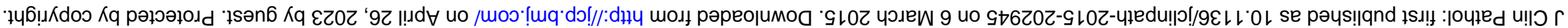


Table 2 Expression of myoid and melanocytic immunohistochemical markers in uterine corpus PEComas

\begin{tabular}{|c|c|c|c|c|c|}
\hline \multicolumn{3}{|c|}{ Immunohistochemistry result } & \multicolumn{3}{|c|}{ Extent of positivity } \\
\hline IHC & $\mathbf{n}$ & Positive (\%) & $\mathbf{n}$ & $\begin{array}{l}<50 \% \text { of } \\
\text { cells }(\%)\end{array}$ & $\begin{array}{l}\geq 50 \% \text { of } \\
\text { cells }(\%)\end{array}$ \\
\hline HMB-45 & 72 & 71/72 (99) & 57 & $31 / 57(54)$ & $26 / 57$ (46) \\
\hline Melan-A & 46 & $21 / 46$ (46) & 20 & $13 / 20(65)$ & $7 / 20$ (35) \\
\hline MiTF & 21 & $14 / 21(66)$ & 12 & $5 / 12(42)$ & $7 / 12$ (58) \\
\hline S100 & 48 & $5 / 48(10)$ & & & \\
\hline Tyrosinase & 3 & $0 / 3(0)$ & & & \\
\hline SMA & 68 & $53 / 68(80)$ & 39 & $16 / 39(41)$ & 23/39 (59) \\
\hline Desmin & 62 & $39 / 62(63)$ & 18 & $7 / 18(39)$ & $11 / 18(61)$ \\
\hline Caldesmon & 22 & $17 / 22(77)$ & 5 & $3 / 5(60)$ & $2 / 5(40)$ \\
\hline Cathepsin & 12 & $12 / 12(100)$ & & & \\
\hline Myosin/MSA & 4 & $2 / 4(50)$ & & & \\
\hline
\end{tabular}

IHC, immunohistochemical; MiTF, microphthalmia-associated transcription factor; PEComas, perivascular epithelioid tumours.

11 (64\%) tumours 54248525970 showed evidence of melanocytic differentiation (presence of premelanosomes or melanosomes).

Reported chromosomal copy number alterations include trisomy $X(n=1)^{61}$ and multiple gains and losses including 16p11.1-p13.3, which contains the TSC2 locus $(n=1) .{ }^{39}$ Conversely, no evidence of LOH at the TSC1 or TSC2 loci was identified in another PEComa. ${ }^{52}$

Twelve patients had evidence of tumour metastasis at the time of diagnosis. $^{2042445455586069}$ Median survival for those who died of disease was 20 months (table 1 ).

\section{Cervix}

Eleven cervical PEComas have been reported. ${ }^{28} 3353$ 73-79 One tumour demonstrated $\mathrm{X}$ polysomy and rearrangement of TFE3, ${ }^{33}$ whereas another tumour showed biallelic somatic deletion of TSC1. ${ }^{78}$ One patient (11\%) recurred locally within 4 months, but had no evidence of disease at 19 months post diagnosis (table 1). ${ }^{79}$

\section{Vagina}

Seven vaginal PEComas have been reported ${ }^{20} 53 \quad 67 \quad 71 \quad 80-82$ (table 1). Three patients were aged $<18$ years. ${ }^{80-82}$

\section{Adnexa}

Six adnexal PEComas have been reported to date. ${ }^{20} 3283-85$ (table 1). A mixed myomelanocytic immunophenotype was demonstrated in five cases. ${ }^{20} 8485$ TFE3 rearrangement was identified in one tumour. ${ }^{32}$ A 63 -year-old patient who died of disease at 4 months had a $15 \mathrm{~cm}$ sclerosing PEComa. ${ }^{84}$ While the presence of severe atypia was noted, the presence of necrosis and mitotic rate was not recorded.

\section{Broad ligament}

Five PEComas of the broad ligament have been reported 2731345386 (table 1). A mixed myomelanocytic immunophenotype was demonstrated in all four tested tumours. ${ }^{27} 313486$ Ultrastructural studies in a single tumour showed premelanosomes, consistent with melanocytic differentiation. ${ }^{31}$

\section{Vulva}

There is a single case report of a vulval/perineal PEComa (table 1). ${ }^{87}$ Ultrastructural studies were negative for premelanosomes.

\section{SUBTYPES OF PECOMA IN THE GYNAECOLOGICAL TRACT PEComatosis}

Six cases of PEComatosis have been described in the gynaecological tract. ${ }^{16-18} 667688$ Median patient age was 43.5 (range 29-70) years. Four (67\%) patients had TSC. ${ }^{16-18} 66$ The dominant tumour mass was located in the uterine corpus $(n=4),{ }^{16-18} 66$ vaginal remnant post hysterectomy $(n=1)^{88}$ and cervix $(n=1){ }^{76}$ Other sites involved by PEComatosis included ovary $(n=4)$, lymph nodes, broad ligament, omentum, peritoneum and small bowel wall. Dominant tumour size ranged from 0.8 to $6 \mathrm{~cm}$ (mean $2.9 \mathrm{~cm}$ ).

The dominant tumours showed mixed epithelioid and spindled morphology (three of four tumours), while one tumour was wholly spindled. ${ }^{16}$ Necrosis was present in one of five cases, ${ }^{18}$ and mitoses ranged from 'rare' and less than or one to 20 per $50 \mathrm{HPF}$. Atypia was noted in four tumours (moderate in three). HMB-45 was positive in five of five cases ('strongly' positive in three of four where extent/intensity was reported), while Melan-A was strongly positive in three of three cases. SMA was positive in six of six cases (three of three strongly positive), while desmin was positive in three of four cases. No ultrastructural studies have been reported in PEComatosis. One case showed balanced chromosomal studies. ${ }^{76}$

Follow-up information was reported in four of six cases; ${ }^{16} \quad 667688$ three of four patients had no evidence of disease after 12 to 168 months of follow-up. One patient was alive with disease at 12 months. ${ }^{88}$

\section{Sclerosing PEComa}

Reported cases have involved the uterine corpus $(\mathrm{n}=9))^{16} \quad 1924 \quad 43 \quad 64$ adnexa $(\mathrm{n}=2)^{84} \quad 85$ and broad ligament $(\mathrm{n}=1) .{ }^{27}$ Two patients had TSC, ${ }^{16} 19$ and one patient had PEComatosis. ${ }^{16}$ Median patient age $(n=11)$ at diagnosis was 46 (range 29-63) years. Mean tumour size $(n=10)$ was $3.75 \mathrm{~cm}$ (range $0.8-15 \mathrm{~cm}$ ). Four tumours were purely epithelioid, one was spindled and one was mixed epithelioid-spindled. No necrosis or atypia was identified $(n=6)$ and no mitotic activity was seen $(n=5)$.

IHC for HMB-45 was positive in nine of nine tumours ('strong' or 'diffuse' positivity in six of eight). Melan-A was negative in five of six cases while MiTF was negative in five of five cases. SMA was strongly and/or diffusely positive in eight of eight tested tumours, while seven of seven tested tumours were positive for desmin (six of seven 'strong' or 'diffuse'). No ultrastructural evidence of melanocytic differentiation was seen in a single tumour. ${ }^{43}$

Nine patients had no disease recurrence with a median follow-up of 19.5 months (range 12-168 months). ${ }^{1619} 24436484$ One patient died of her disease 4 months after diagnosis. ${ }^{84}$

\section{TFE3 translocation-associated PEComa}

TFE3 is a member of the MiTF. Translocations involving the TFE3 locus at Xp11.2 have been reported in epithelioid clear cell tumours such as alveolar soft part sarcoma and Xp11.2 translocation-associated renal cell carcinoma. In recent years, 18 cases of TFE3 translocation-associated PEComa have been reported in kidney, ${ }^{25} 89$ bladder, ${ }^{90}$ colon, ${ }^{91} 92$ pelvic soft tissue, $^{25}$ ovary, ${ }^{32}$ vagina ${ }^{71}$ and uterus. ${ }^{58} 71$ '91 These tumours appear to be characterised by predominantly epithelioid, clear cell morphology without pleomorphism and IHC positivity for HMB-45, TFE3 and Cathepsin K, and negativity for MiTF, ${ }^{91} 92$ SMA and desmin. ${ }^{25} 32719192$ This suggests that TFE3-translocation associated PEComa may represent a distinct subgroup 
Table 3 Folpe criteria for prognosis in PEComa (from Folpe et $a l^{53}$ )

\begin{tabular}{|c|c|c|c|}
\hline & Criteria & $\begin{array}{l}\text { Percentage fulfilling criteria with } \\
\text { aggressive behavior (\%) }\end{array}$ & Comment \\
\hline Benign & $\begin{array}{l}\text { No worrisome features }(<5 \mathrm{~cm} \text {, non-infiltrative, non-high nuclear } \\
\text { grade and cellularity, mitotic rate less than or one per } 50 \mathrm{HPF} \text {, } \\
\text { no necrosis, no vascular invasion) }\end{array}$ & 0 of $22(0)$ & \\
\hline \multirow[t]{2}{*}{$\begin{array}{l}\text { Uncertain malignant } \\
\text { potential }\end{array}$} & Nuclear pleomorphism/multinucleated giant cells only or & 0 of $6(0)$ & $\begin{array}{l}\text { 'Symplastic' PEComa probably benign, } \\
\text { but few reported cases }\end{array}$ \\
\hline & Size $>5 \mathrm{~cm}$ only & 2 of $17(12)$ & $\begin{array}{l}\text { Large tumours should be extensively } \\
\text { sampled to exclude areas with other } \\
\text { worrisome features }\end{array}$ \\
\hline Malignant & $\begin{array}{l}\text { Two or more worrisome features ( }>5 \mathrm{~cm} \text {, infiltrative, high } \\
\text { nuclear grade and cellularity, mitotic rate greater than or one } \\
\text { per } 50 \mathrm{HPF} \text {, necrosis, vascular invasion) }\end{array}$ & 12 of $17(71)$ & \\
\hline
\end{tabular}

within the PEComa family. ${ }^{71}$ Activation of the mTOR pathway may not necessarily play a role in these tumours, which has implications with respect to patient entry into clinical trials of mTOR pathway inhibitors. ${ }^{40}$

PEComas associated with TFE3 translocations are immunoreactive for TFE3, but the converse is not necessarily true; for example, three gynaecological tract PEComas which were TFE3-positive on IHC were negative for TFE3 translocation on fluorescent in-situ hybridisation (FISH). ${ }^{71}$ Since TFE3 is ubiquitously expressed at a low level in many cell types, the use of sensitive IHC techniques may yield positive IHC results in tumours which lack TFE3 translocations. ${ }^{91}$ Therefore, weak IHC staining for TFE3 on should be interpreted with caution. At present, our approach to TFE3-immunoreactive tumours is to perform FISH to confirm the presence of the translocation.

\section{ASSESSMENT OF MALIGNANCY IN UTERINE PECOMA}

The prognostic classification system of Folpe et $a l^{53}$, based on retrospective analysis of 26 PEComas of multiple sites, divided PEComas into benign, uncertain malignant potential (UMP) and malignant groups based on histological criteria (table 3). Subsequently, some deficiencies in this system became apparent. While the categorisation of cases with no worrisome features (benign) or two or more worrisome features (malignant) is straightforward, it is unclear how to categorise those PEComas with a single worrisome feature such as elevated mitotic count, necrosis or infiltrative growth pattern.

Recently, Schoolmeester et $a l^{20}$ applied the Folpe criteria to 16 gynaecological tract PEComas and proposed a revised system (table 4) which set a higher threshold for malignancy (four or more worrisome features) and yielded greater specificity and positive and negative predictive values for subsequent malignant behaviour without sacrificing sensitivity. In addition, they combined the benign and UMP categories into one group, in which no malignant behaviour was observed during the limited follow-up period of the study.

We extracted all reported histological and outcome data from 78 reported uterine PEComas in order to compare the Folpe and Schoolmeester systems. In an attempt to rectify the deficiencies in the Folpe system outlined above, we tested a modification of the Folpe criteria (modified-Folpe), wherein tumours with a single 'worrisome' feature such as maximum dimension of $\geq 5 \mathrm{~cm}$, infiltrative edge, lymphovascular invasion (LVI) or mitotic count greater than one per $50 \mathrm{HPF}$ are considered benign (table 5). It was not possible to define an upper limit to tumour size or mitotic count due to the small number of reported tumours with a single worrisome feature, but pending data from additional cases, clinicians may use their judgment and move the tumour to the UMP category if they consider the mitotic count or tumour size worryingly high (criteria arbitrarily used in this analysis were tumour size $>10 \mathrm{~cm}$ or mitoses greater than three per $50 \mathrm{HPF}$ ). Tumours with isolated marked atypia, maximum dimension $>10 \mathrm{~cm}$ or mitotic count greater than three per $50 \mathrm{HPF}$ in the absence of other worrisome criteria should be considered UMP tumours due to the lack of available data. Since necrosis was the single worrisome feature in only one case, in which the tumour was associated with a lymph node metastasis, ${ }^{55}$ we have placed it in the malignant category.

For our analysis, it was necessary to discard 'cellularity' as a criterion as it is poorly defined and is not assessed in most reports. Furthermore, features such as 'infiltrative edge' and LVI were not explicitly reported in many papers. We assumed that LVI was not identified if it was not explicitly stated as being present. Tumours in which the nature of the advancing edge was not reported were considered non-assessable using the Folpe and Schoolmeester criteria (unless the tumour reached thresholds for malignancy based on other worrisome features).

Table 4 Schoolmeester criteria for prognosis in PEComa (from Schoolmeester et al ${ }^{20}$ )

\begin{tabular}{llll}
\hline & Criteria & $\begin{array}{l}\text { Cases with known } \\
\text { metastasis meeting } \\
\text { criteria (\%) }\end{array}$ & $\begin{array}{l}\text { Cases without known } \\
\text { metastasis meeting } \\
\text { criteria (\%) }\end{array}$ \\
\hline $\begin{array}{l}\text { Benign or uncertain } \\
\text { malignant potential } \\
\text { Malignant }\end{array}$ & $\begin{array}{l}\text { Tumours with less than four features: gross size } \geq 5 \mathrm{~cm} \text {, high-grade nuclear features, } \\
\text { necrosis, vascular invasion, or a mitotic rate greater than or one per } 50 \mathrm{HPF}\end{array}$ & 0 of $9(0)$ & 7 of 7 (100) \\
\hline HPF, high power field; PEComas, perivascular epithelioid tumours. & 9 of $9(100)$ & 0 of $7(0)$ \\
\hline
\end{tabular}


Table 5 Summary of modified-Folpe criteria

\begin{tabular}{|c|c|}
\hline Benign & $\begin{array}{l}\text { Less than or one worrisome feature (including invasive } \\
\text { edge, size } \geq 5 \text { to }<10 \mathrm{~cm} \text {, mitoses two to three per } \\
50 \mathrm{HPF} \text {, lymphovascular invasion) }\end{array}$ \\
\hline $\begin{array}{l}\text { Uncertain malignant } \\
\text { potential }\end{array}$ & $\begin{array}{l}\text { One worrisome feature that includes isolated marked } \\
\text { atypia, size } \geq 10 \mathrm{~cm} \text { or mitotic count greater than or } \\
\text { four per } 50 \mathrm{HPF}\end{array}$ \\
\hline Malignant & Any necrosis or two worrisome features \\
\hline
\end{tabular}

Using both Folpe and modified-Folpe criteria, no benign or UMP tumour behaved in a malignant fashion, although the modified-Folpe criteria allowed more tumours to be categorised and recognised as benign (table 6). The Schoolmeester criteria showed superior specificity and positive predictive value (with all 16 tumours categorised as 'malignant' showing metastasis or local recurrence) than the Folpe and modified-Folpe systems, but seven of 47 tumours (15\%) classified as benign/UMP behaved in a malignant fashion (table 6).

The Folpe and modified-Folpe criteria show greater sensitivities and negative predictive values than the Schoolmeester criteria. However, tumours meeting the more stringent Schoolmeester definition of malignancy frequently recurred early. Until data from larger numbers of tumours are available, the modified-Folpe criteria may be used first to categorise tumours, with subsequent application of the Schoolmeester criteria to help identify malignant tumours at high risk of early recurrence.

\section{CHALLENGES IN DIAGNOSIS OF GYNAECOLOGICAL TRACT PECOMA: THE PECOMA/SMOOTH MUSCLE TUMOUR MORPHOLOGICAL SPECTRUM}

The differential diagnosis of uterine PEComa versus LMS is an area of diagnostic controversy. The diagnosis of uterine PEComa is particularly challenging because of the relative frequency of uterine smooth muscle tumours (SMTs). By middle age, up to $80 \%$ of women are believed to have uterine leiomyomas (LM). ${ }^{93} 94$ PEComas express a myoid immunophenotype and may have spindled morphology and therefore, it is unsurprising that they share many features with common SMTs such as LM and LMS.

While evidence of a myomelanocytic immunophenotype was initially considered a discriminatory feature in favour of PEComa, at least focal positivity for melanocytic markers such as HMB-45, Melan-A and MiTF has been demonstrated in uterine SMTs. ${ }^{95-97}$ In one study of five LMS with spindled and epithelioid morphology, the majority of HMB-45-positive areas exhibited clear cell morphology, but some HMB-45 positivity was also demonstrable in spindled areas. ${ }^{96}$ Evidence of the phenotypic plasticity of LMS is illustrated by a report of the development of a clear cell, diffusely HMB-45-positive, predominantly SMA-negative metastasis from a HMB-45-negative primary epithelioid LMS. ${ }^{95}$ Cathepsin $\mathrm{K}$ was recently promoted as a useful IHC marker for the differential diagnosis between PEComa and LMS, but further study has demonstrated cathepsin $\mathrm{K}$ expression in a proportion of LMS. ${ }^{98}$

Although the uterus is now the most commonly reported extrarenal site for PEComa, ${ }^{14}{ }^{15}$ there has been some controversy as to whether uterine PEComa is a distinct entity. $^{14} 15 \quad 21 \quad 95-9799$ Evidence from four TSC patients with uterine PEComa, in whom the uterine tumour developed in the context of PEComatosis involving multiple gynaecological sites $^{16-18} 88$ appears to confirm the existence of uterine PEComa. However, it is unclear whether a subset of tumours currently diagnosed as sporadic uterine PEComas actually represent uterine SMTs with variant histological and/or IHC features.

There are several reasons for caution when considering a diagnosis of uterine PEComa. First, there is overlap between the histological and IHC features of PEComas and uterine SMTs. While features such as epithelioid appearance, vascular architecture and the presence of spider cells, multinucleate giant cells and macronucleoli are proposed as being characteristic of PEComa, ${ }^{20}$ their use in distinguishing PEComa from uterine SMTs has not been validated. While classical spindled uterine LMS is a straightforward diagnosis in most cases, purely epithelioid LMS (rare) and, more commonly, mixed spindled and epithelioid LMS frequently pose diagnostic dilemmas due to their histopathological overlap with PEComas. As a result, there is variation between pathologists in the diagnosis of PEComa.

Second, criteria for malignancy in uterine LMS are well established, but much less so for PEComa. As discussed, the prognostic system for PEComa is in evolution as it is based on retrospective analyses of small tumour cohorts. ${ }^{20} 53$ A uterine tumour on the morphological spectrum between SMT and PEComa which demonstrates features such as infiltrative margin and increased mitotic activity may be labelled as benign or malignant, according to the classification of the tumour as a SMT or PEComa, respectively. This has major implications for the patient in terms of the risk of overtreatment, inappropriate treatment (eg, mTOR pathway inhibition) and psychological morbidity.

Third, there is little available molecular data. While several small studies of both TSC-associated and sporadic renal AML have confirmed the importance of TSC2 loss-of-function, it has been shown in only three uterine PEComas. ${ }^{39} 40$

Four patients with gynaecological PEComa have been reported to have received mTOR inhibitors (sirolimus and temsirolimus); ${ }^{6978} 100$ follow-up is available on two patients, who died of their disease, at 9 and 10 months, respectively. In none

Table 6 Comparative analysis of PEComa classifications

\begin{tabular}{|c|c|c|c|c|c|c|c|}
\hline \multirow[b]{2}{*}{ Classification } & \multicolumn{2}{|l|}{ Benign } & \multicolumn{2}{|l|}{ UMP } & \multicolumn{2}{|c|}{ Malignant } & \multirow[b]{2}{*}{$\begin{array}{l}\text { Not assessable } \\
\text { Cases, N }\end{array}$} \\
\hline & Cases, N & $\begin{array}{l}\text { Malignant } \\
\text { behaviour, N (\%) }\end{array}$ & Cases, N & $\begin{array}{l}\text { Malignant } \\
\text { behaviour, N (\%) }\end{array}$ & Cases, N & $\begin{array}{l}\text { Malignant } \\
\text { behaviour, N (\%) }\end{array}$ & \\
\hline Folpe & 9 & $0(0)$ & 5 & $0(0)$ & 42 & $29(69)$ & $22^{*}$ \\
\hline Modified-Folpe & 29 & $0(0)$ & 0 & $0(0)$ & 42 & $29(69)$ & 7 \\
\hline Schoolmeestert & 51 & 7 (14) & & & 17 & $17(100)$ & 10 \\
\hline
\end{tabular}

*Fifteen due to Folpe criteria deficits.

†Schoolmeester et al combined the benign and UMP categories.

PEComas, perivascular epithelioid tumours; UMP, uncertain malignant potential. 
of these four cases was LOH or mutation of TSC2 demonstrated nor was activation of the mTOR pathway confirmed. In our opinion, due to interpathologist variation and uncertainty in the diagnosis of uterine PEComa, all tumours accepted into clinical trials of mTOR pathway inhibitors should have molecular analysis to confirm loss of TSC2 and/or loss of function of tuberin with mTOR pathway activation.

\section{CONCLUSION}

What is the practicing pathologist to do when faced with a mixed spindled/epithelioid gynaecological tract tumour with mixed myoid and melanocytic marker expression? Fadare ${ }^{99}$ proposed that morphologically conventional SMTs be labelled as such, even if they focally express melanocytic markers (this should be noted in the report), while classical PEComa should also be diagnosed as such. He proposes that non-classical epithelioid mesenchymal tumours should be labelled as epithelioid tumours of UMP. In our opinion, it would be helpful to include a note in the pathology report explaining the basis for diagnostic uncertainty when using this term. For PEComas, the use of the modified-Folpe and Schoolmeester criteria may provide additional prognostic information to aid patient management. While these guidelines may help in the majority of cases, the ultimate question remains as to what constitutes a PEComa of the gynaecological tract outside of the setting of TSC, and how it can be reproducibly differentiated from SMTs. It is likely that molecular genetic studies will give us greater insight into the nature of gynaecological tract PEComa and its relationship to uterine SMTs and help resolve this ongoing diagnostic dilemma.

\section{Take home messages}

- PEComas of the gynaecological tract are rare tumors, the majority of which are sporadic (not associated with tuberous sclerosis complex) uterine tumors with a mixed myomelanocytic immunophenotype. Unusual tumor variants include sclerosing PEComa and TFE3-translocation associated PEComa.

- The prognostic classification system for PEComa of the gynaecological tract is a work in progress. The modifiedFolpe system described in this paper is a potentially useful tool for prognostic assessment.

- The pathological differential diagnosis between uterine PEComa and leiomyosarcoma variants remains a challenge. Future molecular analysis of sporadic uterine PEComa to test the hypothesised role of TSC2 mutation in tumor development will likely provide valuable insights.

\section{Handling editor Cheok Soon Lee}

Contributors Preparation of initial draft, tables and figures: NC. Review and revision of manuscript and approval of final version of manuscript for submission: all authors.

Competing interests None.

Provenance and peer review Not commissioned; internally peer reviewed.

\section{REFERENCES}

1 Pea M, Bonetti F, Zamboni G, et al. Melanocyte-marker-HMB-45 is regularly expressed in angiomyolipoma of the kidney. Pathology 1991;23:185-8.

2 Ashfaq R, Weinberg AG, Albores-Saavedra J. Renal angiomyolipomas and HMB-45 reactivity. Cancer 1993;71:3091-7.
3 Bonetti F, Pea M, Martignoni G, et al. Clear cell ("sugar)" tumor of the lung is a lesion strictly related to angiomyolipoma--the concept of a family of lesions characterized by the presence of the perivascular epithelioid cells (PEC). Pathology 1994;26:230-6.

4 Zamboni G, Pea M, Martignoni G, et al. Clear cell "sugar" tumor of the pancreas. A novel member of the family of lesions characterized by the presence of perivascular epithelioid cells. Am I Surg Pathol 1996;20:722-30.

5 Pea M, Martignoni G, Zamboni G, et al. Perivascular epithelioid cell. Am I Surg Pathol 1996;20:1149-53.

6 Bonetti F, Pea M, Martignoni G, et al. PEC and sugar. Am J Surg Pathol 1992;16:307-8.

7 Fernandez-Flores A. Evidence on the neural crest origin of PEComas. Rom J Morphol Embryol 2011;52:7-13.

8 Hirschi KK, Majesky MW. Smooth muscle stem cells. Anat Rec A Discov Mol Cell Evol Biol 2004;276:22-33.

9 Toma JG, McKenzie IA, Bagli D, et al. Isolation and characterization of multipotent skin-derived precursors from human skin. Stem Cells 2005;23:727-37.

10 Reiman HM, Goellner JR, Woods JE, et al. Desmoplastic melanoma of the head and neck. Cancer 1987;60:2269-74.

11 Banerjee SS, Bishop PW, Nicholson CM, et al. Malignant melanoma showing smooth muscle differentiation. J Clin Pathol 1996;49:950-1.

12 Crino PB, Nathanson KL, Henske EP. The tuberous sclerosis complex. N Engl J Med 2006;355:1345-56.

13 Hornick JL, Fletcher CD. PEComa: what do we know so far? Histopathology 2006;48:75-82.

14 Fadare 0. Perivascular Epithelioid Cell Tumors (PEComas) and Smooth Muscle Tumors of the Uterus. Am J Surg Pathol 2007;31:1454-5; author reply 1455-6.

15 Fadare 0 . Perivascular epithelioid cell tumor (PEComa) of the uterus: an outcome-based clinicopathologic analysis of 41 reported cases. Adv Anat Pathol 2008;15:63-75.

16 Fang $\mathrm{CL}$, Lin YH, Chen WY. Microscopic endometrial perivascular epithelioid cell nodules: a case report with the earliest presentation of a uterine perivascular epithelioid cell tumor. Diagn Pathol 2012;7:117.

17 Froio E, Piana S, Cavazza A, et al. Multifocal PEComa (PEComatosis) of the female genital tract associated with endometriosis, diffuse adenomyosis, and endometrial atypical hyperplasia. Int I Surg Pathol 2008;16:443-6.

18 Liang SX, Pearl M, Liu J, et al. "Malignant" uterine perivascular epithelioid cell tumor, pelvic lymph node lymphangioleiomyomatosis, and gynecological pecomatosis in a patient with tuberous sclerosis: a case report and review of the literature. Int I Gynecol Pathol 2008;27:86-90.

19 Lim GS, Oliva E. The morphologic spectrum of uterine PEC-cell associated tumors in a patient with tuberous sclerosis. Int I Gynecol Pathol 2011;30: $121-8$.

20 Schoolmeester JK, Howitt BE, Hirsch MS, et al. Perivascular epithelioid cell neoplasm (PEComa) of the gynecologic tract: clinicopathologic and immunohistochemical characterization of 16 cases. Am J Surg Pathol 2014;38:176-88.

21 Carvalho FM, Carvalho JP, Maluf FC, et al. A new morphological variant of uterine PEComas with sex-cord-like pattern and WT1 expression: more doubts about the existence of uterine PEComas. Ann Diagn Pathol 2010;14: 129-32.

22 Korytnaya E, Liu J, Camelo-Piragua S, et al. Ectopic prolactin secretion from a perivascular epithelioid cell tumor (PEComa). I Clin Endocrinol Metab 2014;99:3960-4.

23 Proust-Lemoine $\mathrm{E}$, Mitchell V, Deruelle $\mathrm{P}$, et al. Ectopic hyperprolactinaemia in a woman with a mesocolic perivascular epithelioid cell tumor ("PEComa)". Ann Endocrinol (Paris) 2008;69:240-3.

24 Hornick JL, Fletcher CD. Sclerosing PEComa: clinicopathologic analysis of a distinctive variant with a predilection for the retroperitoneum. Am J Surg Pathol 2008:32:493-501.

25 Shen Q, Rao Q, Xia QY, et al. Perivascular epithelioid cell tumor (PEComa) with TFE3 gene rearrangement: clinicopathological, immunohistochemical, and molecular features. Virchows Arch 2014;465:607-13.

26 Martignoni $G$, Bonetti $F$, Chilosi $M$, et al. Cathepsin $\mathrm{K}$ expression in the spectrum of perivascular epithelioid cell (PEC) lesions of the kidney. Mod Pathol 2012;25:100-11.

27 Rao Q, Cheng L, Xia QY, et al. Cathepsin K expression in a wide spectrum of perivascular epithelioid cell neoplasms (PEComas): a clinicopathological study emphasizing extrarenal PEComas. Histopathology 2013;62:642-50.

28 Zhang C, Pan F, Qiao J, et al. Perivascular epithelioid cell tumor of the cervix with malignant potential. Int J Gynaecol Obstet 2013;123:72-3.

29 Gaffey MJ, Mills SE, Zarbo RJ, et al. Clear cell tumor of the lung. Immunohistochemical and ultrastructural evidence of melanogenesis. Am J Surg Pathol 1991;15:644-53.

30 Kaiserling E, Krober S, Xiao JC, et al. Angiomyolipoma of the kidney. Immunoreactivity with HMB-45. Light- and electron-microscopic findings. Histopathology 1994;25:41-8.

$31 \mathrm{Kim} \mathrm{HJ}$, Lim SJ, Choi H, et al. Malignant clear-cell myomelanocytic tumor of broad ligament--a case report. Virchows Arch 2006;448:867-70. 
32 Lee SE, Choi YL, Cho J, et al. Ovarian perivascular epithelioid cell tumor not otherwise specified with transcription factor $\mathrm{E} 3$ gene rearrangement: a case report and review of the literature. Hum Pathol 2012;43:1126-30.

33 Liu F, Zhang R, Wang ZY, et al. Malignant perivascular epithelioid cell tumor (PEComa) of cervix with TFE3 gene rearrangement: a case report. Int I Clin Exp Pathol 2014:7:6409-14.

34 Rys J, Karolewski K, Pudelek J, et al. Perivascular epithelioid tumor (PEComa) of the falciform/ broad ligament. Pol J Pathol 2008:59:211-15.

35 Henske EP, Neumann HP, Scheithauer BW, et al. Loss of heterozygosity in the tuberous sclerosis (TSC2) region of chromosome band 16p13 occurs in sporadic as well as TSC-associated renal angiomyolipomas. Genes Chromosomes Cancer 1995:13:295-8.

36 Smolarek TA, Wessner LL, McCormack FX, et al. Evidence that lymphangiomyomatosis is caused by TSC2 mutations: chromosome 16p13 loss of heterozygosity in angiomyolipomas and lymph nodes from women with lymphangiomyomatosis. Am J Hum Genet 1998;62:810-5.

37 Wullich B, Henn W, Siemer S, et al. Clonal chromosome aberrations in three of five sporadic angiomyolipomas of the kidney. Cancer Genet Cytogenet 1997:96:42-5.

38 Carsillo T, Astrinidis A, Henske EP. Mutations in the tuberous sclerosis complex gene TSC2 are a cause of sporadic pulmonary lymphangioleiomyomatosis. Proc Natl Acad Sci USA 2000:97:6085-90.

39 Pan CC, Jong YJ, Chai CY, et al. Comparative genomic hybridization study of perivascular epithelioid cell tumor: molecular genetic evidence of perivascular epithelioid cell tumor as a distinctive neoplasm. Hum Pathol 2006;37:606-12.

40 Malinowska I, Kwiatkowski DJ, Weiss S, et al. Perivascular epithelioid cell tumors (PEComas) harboring TFE3 gene rearrangements lack the TSC2 alterations characteristic of conventional PEComas: further evidence for a biological distinction. Am J Surg Pathol 2012;36:783-4.

41 Kenerson H, Folpe AL, Takayama TK, et al. Activation of the mTOR pathway in sporadic angiomyolipomas and other perivascular epithelioid cell neoplasms. Hum Pathol 2007:38:1361-71.

42 Ruco LP, Pilozzi E, Wedard BM, et al. Epithelioid lymphangioleiomyomatosis-like tumour of the uterus in a patient without tuberous sclerosis: a lesion mimicking epithelioid leiomyosarcoma. Histopathology 1998;33:91-3.

43 Michal M, Zamecnik M. Hyalinized uterine mesenchymal neoplasms with HMB-45-positive epithelioid cells: epithelioid leiomyomas or angiomyolipomas? Report of four cases. Int J Surg Pathol 2000;8:323-8.

44 Bonetti F, Martignoni G, Colato C, et al. Abdominopelvic sarcoma of perivascular epithelioid cells. Report of four cases in young women, one with tuberous sclerosis. Mod Pathol 2001;14:563-8.

45 Vang R, Kempson RL. Perivascular epithelioid cell tumor ('PEComa') of the uterus: a subset of HMB-45-positive epithelioid mesenchymal neoplasms with an uncertain relationship to pure smooth muscle tumors. Am J Surg Pathol 2002;26: $1-13$.

46 Dimmler A, Seitz $G$, Hohenberger W, et al. Late pulmonary metastasis in uterine PEComa. J Clin Pathol 2003;56:627-8.

47 Greene LA, Mount SL, Schned AR, et al. Recurrent perivascular epithelioid cell tumor of the uterus (PEComa): an immunohistochemical study and review of the literature. Gynecol Oncol 2003;90:677-81.

48 Park SH, Ro JY, Kim HS, et al. Perivascular epithelioid cell tumor of the uterus: immunohistochemical, ultrastructural and molecular study. Pathol Int 2003:53:800-5

49 Darai $\mathrm{E}$, Bazot $\mathrm{M}$, Barranger $\mathrm{E}$, et al. Epithelioid angiomyolipoma of the uterus: a case report. J Reprod Med 2004;49:578-81.

50 Gao Z, Bhuiya T, Anderson A. Perivascular epithelioid cell tumour (PEComa) of the uterus associated with malignant neoplasm of the female genital tract. J Obstet Gynaecol 2004;24:600-4.

51 Bernardo Bega R, Camino FB, Fernandez MDC, et al. The PEComa tumor: could it be considered an independent neoplastic entity. J Gynecol Surg 2005;21: 161-6.

52 Bosincu L, Rocca PC, Martignoni G, et al. Perivascular epithelioid cell (PEC) tumors of the uterus: a clinicopathologic study of two cases with aggressive features. Mod Pathol 2005; 18:1336-42.

53 Folpe AL, Mentzel T, Lehr HA, et al. Perivascular epithelioid cell neoplasms of soft tissue and gynecologic origin: a clinicopathologic study of 26 cases and review of the literature. Am J Surg Pathol 2005;29:1558-75.

54 Fukunaga M. Perivascular epithelioid cell tumor of the uterus: report of four cases. Int J Gynecol Pathol 2005;24:341-6.

55 Jeon IS, Lee SM. Multimodal treatment using surgery, radiotherapy, and chemotherapy in a patient with a perivascular epithelioid cell tumor of the uterus. J Pediatr Hematol Oncol 2005;27:681-4.

56 Rammeh Rommani S, Trabelsi A, Attia L, et al. Perivascular epithelioid cell tumor of the uterus: a case report. Pathologica 2006;98:649-51.

57 Gan MF, Yu CK, Jin M, et al. Perivascular epithelioid cell tumor of the uterus: report of three cases. Chin Med J (Engl) 2007;120:526-8.

58 Cho HY, Chung DH, Khurana $\mathrm{H}$, et al. The role of TFE3 in PEComa. Histopathology 2008;53:236-49.
59 Yavuz E, Cakr C, Tuzlal S, et al. Uterine perivascular epithelioid cell tumor coexisting with pulmonary lymphangioleiomyomatosis and renal angiomyolipoma: a case report. Appl Immunohistochem Mol Morphol 2008;16:405-9.

60 Liu JL, Lin YM, Lin MC, et al. Perivascular epithelioid cell tumor (PEComa) of the uterus with aggressive behavior at presentation. Hematol Oncol Stem Cell Ther 2009:2:426-30

61 Yamagata Y, Kawauchi S, Tamura H, et al. A case of HMB45-negative perivascular epithelioid cell tumor (PEComa) of the uterine corpus: a possible diagnostic application of molecular-cytogenetic analysis. Eur J Gynaecol Oncol 2009;30: 216-9.

62 Clay MR, Gibson P, Lowell J, et al. Microscopic uterine lymphangioleiomyomatosis perivascular epithelioid cell neoplasm: a case report with the earliest manifestation of this enigmatic neoplasm. Int J Gynecol Pathol 2011;30:71-5.

63 Horn LC, Einenkel J. Uterine perivascular epitheloid cell tumor (PEComa) with CD117 and PNL2 positivity and entrapped endometriotic glands, mimicking sex-cordlike differentiation. Ann Diagn Pathol 2011;15:216-18.

64 Yamada $Y$, Yamamoto $H$, Ohishi $Y$, et al. Sclerosing variant of perivascular epithelioid cell tumor in the female genital organs. Pathol Int 2011;61: 768-72.

65 Bleeker JS, Quevedo JF, Folpe AL. Malignant perivascular epithelioid cell tumor of the uterus. Rare Tumors 2012:4:e14

66 Yang W, Li G, Wei-giang Z. Multifocal PEComa (PEComatosis) of the female genital tract and pelvis: a case report and review of the literature. Diagn Pathol 2012;7:23.

67 Ye HY, Chen JG, Luo DL, et al. Perivascular epithelioid cell tumor (PEComa) of gynecologic origin: a clinicopathological study of three cases. Eur J Gynaecol Oncol 2012;33:105-8.

68 Cossu A, Paliogiannis P, Tanda F, et al. Uterine perivascular epithelioid cell neoplasms (PEComas): report of two cases and literature review. Eur J Gynaecol Oncol 2014:35:309-12

69 Ghosh I, Arun I, Sen S, et al. Metastatic perivascular epithelioid cell tumor responding to mammalian target of rapamycin inhibition. Indian J Med Paediatr Oncol 2014;35:99-102.

70 Okada H, Terado Y, Fujiwara $\mathrm{M}$, et al. Perivascular epithelioid cell tumor of the uterus. Pathol Int 2014;64:151-3.

71 Schoolmeester JK, Dao LN, Sukov WR, et al. TFE3 Translocation-associated Perivascular Epithelioid Cell Neoplasm (PEComa) of the Gynecologic Tract: morphology, immunophenotype, differential diagnosis. Am J Surg Pathol 2015;39:394-404.

72 Yu Y, Shi HY, Huang HF. Uterine perivascular epithelioid cell tumour. J Obstet Gynaecol 2014;34:519-22.

73 Azad NS, Aziz AB, Pervez S, et al. Uterine perivascular epithelioid cell tumour presenting as a cervical mass. J Pak Med Assoc 2006;56:83-4.

74 Bradshaw MJ, Folpe AL, Croghan GA. Perivascular epithelioid cell neoplasm of the uterine cervix: an unusual tumor in an unusual location. Rare Tumors 2010;2:e56.

75 Celik H, Kefeli M, Cetinkaya M, et al. Perivascular Epithelioid Cell Tumor (PEComa) of the Uterine Cervix in a Patient with Tuberous Sclerosis Complex: A Literature Review. Turk Patoloji Derg 2014;11:1-5.

76 Fadare 0, Parkash V, Yilmaz Y, et al. Perivascular epithelioid cell tumor (PEComa) of the uterine cervix associated with intraabdominal "PEComatosis" a clinicopathological study with comparative genomic hybridization analysis. World I Surg Oncol 2004;2:35.

77 Natella V, Merolla F, Giampaolino P, et al. A huge malignant perivascular epithelioid cell tumor (PEComa) of the uterine cervix and vagina. Pathol Res Pract 2014;210:186-8.

78 Wagner AJ, Malinowska-Kolodziej I, Morgan JA, et al. Clinical activity of mTOR inhibition with sirolimus in malignant perivascular epithelioid cell tumors: targeting the pathogenic activation of mTORC1 in tumors. J Clin Oncol 2010;28: 835-40.

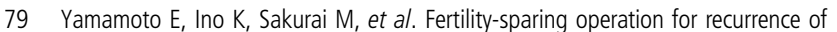
uterine cervical perivascular epithelioid cell tumor. Rare Tumors 2010;2:e26.

80 Kalyanasundaram K, Parameswaran A, Mani R. Perivascular epithelioid tumor of urinary bladder and vagina. Ann Diagn Pathol 2005;9:275-8.

81 Ong LY, Hwang WS, Wong A, et al. Perivascular epithelioid cell tumour of the vagina in an 8 year old girl. J Pediatr Surg 2007;42:564-6.

82 Cho HJ, Lee MK, Kang BM, et al. A 6-year-old girl with vaginal spotting who was diagnosed with perivascular epithelioid cell neoplasm after vaginoscopic resection. Obstet Gynecol Sci 2014;57:409-11.

83 Anderson $A E$, Yang $X$, Young $R H$. Epithelioid angiomyolipoma of the ovary: a case report and literature review. Int J Gynecol Pathol 2002;21:69-73.

84 Ramaiah S, Ganesan R, Mangham DC, et al. Malignant variant of sclerosing perivascular epithelioid cell tumor arising in the adnexa. Int I Gynecol Pathol 2009:28:589-93.

85 Surico D, Codeca C, Boldorini R, et al. Sclerosing PEComa: a case report and review of the literature. Minerva Chir 2013;68:125-8.

86 Fink D, Marsden DE, Edwards L, et al. Malignant perivascular epithelioid cell tumor (PEComa) arising in the broad ligament. Int J Gynecol Cancer 2004;14:1036-9.

87 Tazelaar HD, Batts KP, Srigley JR. Primary extrapulmonary sugar tumor (PEST) a report of four cases. Mod Pathol 2001;14:615-22. 
88 Salviato T, Altavilla G, Busatto G, et al. Diffuse intra-abdominal clear cell myomelanocytic tumor: report of an unusual presentation of "PEComatosis" simulating peritoneal mesothelioma. Ann Diagn Pathol 2006;10:352-6.

89 Ohe $\mathrm{C}$, Kuroda $\mathrm{N}$, Hes $\mathrm{O}$, et al. A renal epithelioid angiomyolipoma/perivascular epithelioid cell tumor with TFE3 gene break visualized by FISH. Med Mol Morphol 2012:45:234-7.

90 Williamson SR, Bunde PJ, Montironi R, et al. Malignant perivascular epithelioid cell neoplasm (PEComa) of the urinary bladder with TFE3 gene rearrangement: clinicopathologic, immunohistochemical, and molecular features. Am I Surg Pathol 2013:37:1619-26.

91 Argani P, Aulmann S, Illei PB, et al. A distinctive subset of PEComas harbors TFE3 gene fusions. Am J Surg Pathol 2010;34:1395-406.

92 Tanaka M, Kato K, Gomi K, et al. Perivascular epithelioid cell tumor with SFPQ/ PSF-TFE3 gene fusion in a patient with advanced neuroblastoma. Am J Surg Pathol 2009;33:1416-20.

93 Baird DD, Dunson DB, Hill MC, et al. High cumulative incidence of uterine leiomyoma in black and white women: ultrasound evidence. Am J Obstet Gynecol 2003;188:100-7.
94 Brooks SE, Zhan M, Cote T, et al. Surveillance, epidemiology, and end results analysis of 2677 cases of uterine sarcoma 1989-1999. Gynecol Oncol 2004;93: 204-8.

95 Silva EG, Bodurka DC, Scouros MA, et al. A uterine leiomyosarcoma that became positive for HMB45 in the metastasis. Ann Diagn Pathol 2005;9:43-5.

96 Silva EG, Deavers MT, Bodurka DC, et al. Uterine epithelioid leiomyosarcomas with clear cells: reactivity with HMB-45 and the concept of PEComa. Am J Surg Pathol 2004;28:244-9.

97 Simpson KW, Albores-Saavedra J. HMB-45 reactivity in conventional uterine leiomyosarcomas. Am I Surg Pathol 2007;31:95-8.

98 Zheng G, Martignoni G, Antonescu C, et al. A broad survey of cathepsin K immunoreactivity in human neoplasms. Am I Clin Pathol 2013;139: $151-9$.

99 Fadare 0 . Uterine PEComa: appraisal of a controversial and increasingly reported mesenchymal neoplasm. Int Semin Surg Oncol 2008;5:7.

100 Benson C, Vitfell-Rasmussen J, Maruzzo M, et al. A retrospective study of patients with malignant PEComa receiving treatment with sirolimus or temsirolimus: the Royal Marsden Hospital experience. Anticancer Res 2014;34:3663-8. 